\title{
Choices and Contexts in India's Constitutional Founding
}

\section{Philipp Dann ${ }^{1}$}

Accepted: 10 December 2021 /Published online: 21 February 2022

(c) The Author(s) 2022

\begin{abstract}
'India's founding moment' a moment of breath-taking political imagination and it is one of the great achievements of Madhav Khosla. to unpack important parts of its pre-history and emergence. This article will look at two questions-one about alternatives and the other about contexts. Regarding alternatives, I am interested in the paths not taken and an understanding of possibilities. I try to get a sense of possible alternative futures or modernities that the founding generation pondered, in the best case allowing us to wonder what we can learn from the choices made as well as from the paths rejected. The other question I raise is the question of the intellectual contexts, in which the founding took place. Coming from a non-Indian perspective, I am interested in the entanglements, the contexts and potentially migrating ideas that emerge.
\end{abstract}

Keywords Constitutional ideas · Contextual analysis $\cdot$ Alternative modernities

India's founding is not the first instance of postcolonial democratic constitutionmaking outside the West. Many nations in Latin America had done so in the nineteenth century. India's Constitution is also not the first to opt for universal franchise. In fact, many new constitutions written around the time did so (Ireland 1922, Brazil and Turkey 1934, Philippines 1937, South Korea 1948).

But India's founding moment is nonetheless a moment of breath-taking political imagination. Emerging from centuries of hierarchical social ordering and colonial suppression and in an unparalleled context of religious and cultural diversity in a continental-size polity, the Indian Constitutional Assembly adopted the model of egalitarian democracy. It posited that regarding every person as equal citizen and equally important agent of self-rule would be the best path to a just society. As much as that surprised observers at the time, what has puzzled generations of writers ever since is that it brought about an unusually stable and enduring constitutional

Philipp Dann

sekretariat.dann@rewi.hu-berlin.de

1 Humboldt-Universität zu Berlin, Berlin, Germany 
democracy. Even though much of the Constitution is still a promise, this Constitution marked its 70th birthday last year and India is rightfully considered the largest democracy in the world.

The pre-history and emergence of this constitution is a central but still hardly studied factor that contributed to this unexpected success. The Indian Constitution of 1950 was not written overnight but emerged from decades-long discussions, in which a great number of politicians and intellectuals inside and outside the independence movement debated the future contours of a free India. This long gestation period allowed for various ideas to be floated, to be revised, to be reconceived. When the Constitutional Assembly started convening, it was able to draw from these various debates.

It is one of the great achievements of Madhav Khosla's book to unpack important parts of this pre-history and emergence. He argues that in the moment of founding three fundamental choices were made (for a written constitution, for a centralized state and for individual representation) and examines the rich and complex history of how these choices came about. Analyzing close-up the discussions around a constitutional model for India, it is a study of the intellectual history of the Indian constitution. It stars and examines in particular the writings of Bim Rao Ambedkar, Jawaharlal Nehru and Mohandas Ghandi but also a number of others, giving testament to the impressive breadth and depth of the Indian political discourse in the first half of the twentieth century. The book's approach rests on the assumption that ideas matter. In that it moves away from the concentration on the political or social history of India's founding that has dominated the discussions so far and is a significant contribution to a recent surge in scholarship engaging with the political theory of Indian constitutionalism (Kumar 2015; Gopal Jayal 2013; Bajpai 2015; Zachariah 2005).

Such an analysis of the intellectual pre-history triggers a number of intriguing perspectives and questions. I will look at Khosla's study of India's founding by focusing on two questions - one about alternatives and the other about contexts. Regarding alternatives, I am interested in the paths not taken and how Khosla in that sense illuminates our understanding of possibilities. By delving into the multifacetted discussions about India's future in the first half of the century, as they partly emerge in Khosla's depiction of the pre-history, we should get a sense of possible alternative futures or modernities that the founding generation pondered, in the best case allowing us to wonder what we can learn from the choices made as well as from the paths rejected.

The other question that the book raises is the question of the intellectual contexts, in which the founding took place. Coming from a non-Indian perspective, I am interested in the entanglements, the contexts and potentially migrating ideas that emerge in Khosla's analysis of the Constitution's intellectual roots. The Indian Constitution (quite in contrast to many postcolonial constitutions, not least in the Commonwealth) is emphatically an Indian product but its authors were anything but parochial; if anything especially the leading figures were well-read and well-travelled. As we understand constitutionalism today increasingly as a world-wide enterprise, the Indian founding might provide insights into earlier paths of intellectual transfer and the connections drawn in its writing (Sujit 2007).

These questions and this short contribution are driven by my interest in the comparative context of Indian constitutionalism and the varieties of constitutionalism 
more generally (Dann and Thiruvengadam, 2021; Dann 2020). The scholarly debates in comparative constitutional law today finally include not just the well-known Western stories but start becoming global. In this frame, my particular interest is in a comparative law of democracy - and here, India's postcolonial, constitutional democracy in the context of immense cultural diversity and economic disparity is a central case study. Interestingly, while there is a considerable amount of literature dealing with India's democracy from the perspective of political theory, political economy and political sociology, ${ }^{1}$ there is a certain dearth in legal and constitutional scholarship engaging not just in specific parts (such as election law) but in the overall concept of democracy. This gap might have to do with the palatable preference of Indian (and most common law) legal scholars to focus on case law, not concepts. But whatever its reasons, Khosla's book might offer a new look. So let's turn to his analysis and the questions of alternative visions and intellectual contexts.

\section{Codification or the Education of the Powers to Be}

The first chapter makes a fascinating argument about form and function of the new constitution. Khosla argues that next to the form elements (rights, state, representation) the Constitution is informed and inspired by a pedagogic function, a rationale or even morale, providing readers of the mere text with a basic understanding and a telos. The inaugural moment of this education is the codification and Constitutionmaking itself. In this constructivist reading, the Constitution serves in particular one important pedagogical purpose: to educate citizens and turn colonial subjects into democratic citizens.

Khosla takes the very size of the Constitution as evidence of its pedagogical intentions. In providing as much detail as possible, he argues, the constitutional legislature wanted to guide the readers. Interestingly, the educational function of the Constitution according to Khosla is not just aiming at the citizens but perhaps even more so at the legislature and the courts. Khosla outlines how the Constitution gives guidance with respect to socio-economic directives, limitations of rights and due process, and in this explicitness and length actually is distrusting the other branches' work and making sure that they would faithfully execute the founders' intentions.

How could it have been different? What alternatives shine through Khosla's analysis? And how does this compare to other constitution-making experiences at the time? The alternative to this written codified constitution would hardly have been an unwritten constitution but perhaps a shorter and less explicit text. For this, the US constitution could have been a role model. But then again, the Indian Constitution takes a decidedly different approach and appears much more as a child of its time. To see and appreciate this, a sense of context is necessary and would have benefited Khosla's analysis and argument. Let me exemplify this with two observations.

For one, the constructivist understanding of the educational purpose and function of the Constitution resonates with similar approaches and experiences around the

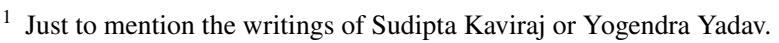


world at the time (and ever since) that are not spelled out in Khosla's description. The idea to deploy a new constitution as an instrument of rupture and as a tool for re-education is perhaps even a universal strategy. In fact, in Germany, from where I am writing, the same goal inspired not only Allied and US policy towards (West-) German constitution-making in 1948-1949 but also the German protagonists themselves. The German constitution of 1949 was meant to draw a direct and teachable contrast to Nazi-ideology. Surely, the contexts were very different but perhaps even more promising in India than in Germany. Khosla cites poverty and illiteracy as reasons for doubts about the prospects of a democratic constitution, like many Western observers had also done at the time. But on the other hand, the Indian Constitutional legislature built on and continued the spirit of the independence movement, which had fought the British for decades and had been turned into a mass movement since the 1920s. Illiterate or poor, Indians had thereby demonstrated more democratic agency than the (supposedly) literate and well-fed Germans. ${ }^{2}$ Providing such contexts would have made the Indian approach even more astounding.

In a second way, the study might have benefited from context to appreciate the educative function of the Constitution, namely the inclusion of socio-economic principles and a material dimension to the Constitution. Khosla discusses this decision as another way of the constitution-makers to educate the legislature. Famously, Ambedkar and Nehru stressed how a constitution would not only have to regulate political power but also private and economic power. The directive principles (and other references to social justice) are then a nod to the importance of social democracy and an important tool to guide future political powers to heed this insight. But also in this respect, the Indian Constitution is not unique but rather a child of its time: The Mexican (1917), the German (1919/1949) or the Korean constitutions (1948) and surely many others understood that constitutionalism in the twentieth century had to have a material dimension, whether you framed it as 'welfare' or 'development'. In terms of intellectual lineage, this is a note-worthy and surely consequential reference to the more materially minded French constitutional tradition, and a rejection of US-style constitutionalism. Today, after decades of (neo-)liberal reforms and increasing abdication of state responsibility for education, infrastructure, welfare, etc., this is an important reminder of how different India's constitutional journey was intended. Here again, Khosla's study would have benefited from providing this context to indicate how the Indian example compares or stand out.

\section{State or the Federal Indifference}

The second chapter examines the intellectual roots and political debates about the form of public authority and the founders' decision for a centralized Indian state. Khosla recounts a fascinating debate, in which alternative visions of modernity were formulated and a variety of models of organizing a polity came to the fore.

\footnotetext{
${ }^{2}$ In fact, to some the more fascinating question and surprising fact is that Indians chose a path of incremental, constitutionally guided reform, while others at the time and in comparable circumstances (think of the USSR or China) chose revolution.
} 
He describes alternative, pluralist conceptions of a village republic (in particular by Mohandas Gandhi and by the economist and sociologist Radhakamal Mukherjee). Both grappled with a non-Western path of modernity, but were met with strong resistance against such fragmentation in Ambedkar and Nehru. The latter feared the forces of localism and wanted to create the preconditions for equal individual citizenship. They saw a strong and that meant in their conception: a centralized state as an essential precondition and vehicle of development and industrialization.

It was the partition that (in Khosla's description) decisively ended those discussions and brought the decision for a centralized state. Partition's impact and the anxiety over chaos caused by too much regional autonomy ended any support for alternative forms of political organization. It is hence ultimately an argument of political sociology that extinguished openness to alternative forms and cleared that there was simply no faith in regional units to have capacity to quell violence.

As much as Khosla presents these two alternatives, it is surprising that he does not discuss a third alternative of constitutional design, namely federalism. This surprises as there is of course a wide conceptual gap between the concepts of a village republic (as proposed by Gandhi) and a centralized state (as favoured by Ambedkar and Nehru) and there must have been a more serious engagement with federal arrangements at the time and among the leading figures. Federal models could have provided more potential for democratic governance and civic engagement, which the founders valued so highly when creating the constitutional framework. With hindsight, one can even argue that the federal structure of the Indian state was central to its preservation in the years to come.

Here again, examples from the global context in which Indian debates and thinking took place are fascinating and instructive. Nehru's and Ambedkar's thinking was to some extent in line with trends in US-American federalism of the time, where the Roosevelt administration worked hard to increase the regulatory reach of the central federal level by promoting the New Deal and hence a model of increased centralization in the name of economic progress. But such centralizing tendencies here as in other federations rest, of course, on the bedrock assumption that the federal division of power is a central bulwark against authoritarianism. A chilling example of this 'democratic lesson' of federalism, if you want, had just been demonstrated in Germany, where one of the first measures of the incoming Nazi regime had been to eliminate the federal structure. Another fascinating context, which is admittedly only available in historical hindsight, is the project of European integration that started around that time. Here, new federal or multilevel arrangements were tested to connect better existing states (just as the Indian Union needed to integrate the multitude of princely states) and do so through economic integration and economic development, while preserving democratic standards.

\section{Representation Without Political Parties}

The third constitutional choice that the Indian constitutional authors took and that Khosla analyzes concerns the question of representation. This posed a special dilemma in a society characterized by a huge variety of religious, cultural, caste, 
language or other identities. Here in particular, the choices and alternatives offered were stark and the debates were multi-layered and complex. Khosla intriguingly juxtaposes the debates about religion and caste, hence two markers of identity that are treated categorically different in the Indian Constitution: While religion is not recognized as relevant for representation, the Constitution contains special representative reservations for certain castes.

The treatment of religious identities in the future India was obviously a major theme in the years preceding independence and four alternative visions were debated: one of territorial separation (advanced by Jinnah and the Muslim League), one of hierarchical ordering (advanced by Hindu nationalists), one of communal segregation (introduced by British) and finally one of individual representation. The last, which won out, was according to Khosla based on two rationales and roots. For Nehru in particular, it was the obvious fallback position, rejecting vehemently any collective representation as medieval and incompatible with modern ideas of political agency in a nation-state. For him, just as for Gandhi, communalism was a 'myth' and no valid reason. Only Ambedkar seemed sensitive to the fact and problems of communalism and pondered extensively the problem of Pakistan; but also for him, only individual representation was a viable long-term way to make trust and communication among the citizenry and across communal lines possible. Again, it was partition that seems to have forced the decision. The Constitutional Assembly's choice for individual representation, according to Khosla, was hardly contested. The decision was underlined by different rationales. For some, communal representation was directly connected to the failing politics and policies of colonialism and therefore a dead end. Others formulated the more constructivist model that regards the individual as agent of political action and identity.

Debates about alternatives with regard to caste identities and their constitutional treatment were very different. Here, Ambedkar is the only intellectual protagonist, whose ideas Khosla examines in more detail and who seemed to have framed the issue for the constitutional debate but in a very different key. While there seem to have been little disagreement about the aim to protect religion but to overcome castes, ${ }^{3}$ the proposals diverge. In contrast to Gandhi, who seem to have assumed that caste should not be highlighted, Ambedkar favoured a much more direct constitutional and ultimately political engagement with caste. He argued for turning it into a criterion of political representation to create political power to overcome it.

As much as the alternative paths become apparent, the intellectual context beyond India's borders remains vague again in Khosla's study. To some extent, this might simply reflect and demonstrate how the Indian political and constitutional debates preceded debates elsewhere by decades. In the West, there is a serious engagement with identities as relevant category of representation only since the 1980s. But on the other hand, one wonders whether more is to be gained from a look at further

\footnotetext{
3 What distinguishes religion and caste and hence justifies their different constitutional treatment is the ultimate aim of regulation. While religious identities are obviously not only allowed by actually respected and protected under the Indian Constitution, caste identities are ultimately to be overcome. Caste as a category was to be annihilated.
} 
contexts. Only a timid connection is made between Ambedkar's thinking on caste and the US-American discussions on race. There is surely more to be discovered. Conspicuously absent in the debate about representation as depicted by Khosla is also the role of political parties, especially considering how multi-facetted and complex the arguments for individual representation and its connection to political parties were already at the time. Political parties are meant to create ideological allegiance and interest allocation and thereby replace religious or communal identities as main markers of political identity. One wonders whether these arguments played any role. A fascinating place to compare and contrast with would again be Germany. By the time, the Indian and the German post-war constitutions were debated, constitutional thinking in Germany had shifted significantly. While there was a considerable mistrust against political parties as destructive agents of political bickering and putting (class/group/...) interests over the common good, post-Nazi constitutional scholars realized the important role of political parties in aggregating positions, organizing interests, connecting civil society and state organization-and last but not least as a bulwark of representative democracy against authoritarian and other enemies. Recognizing this, the new German Constitution of 1949 places political parties at a central place but also demands that they are internally democratic and transparent. To some extent, these were lessons from a failed constitutional order (the Weimar Republic) and not from colonial authoritarianism, but their reflection would surely shed light on the Indian path. ${ }^{4}$

\section{Concluding Observations}

Madhav Khosla provides an impressive analysis of the complex and rich intellectual history of the Indian Constitution. His book is a major contribution to our understanding of one of the world's most influential and admired constitutional systems. His study, like most profound and rich pieces of intellectual work, triggers a large number of thoughts and ideas but also raises questions and sharpens our sense for desiderata and lacunae in the field. I would therefore like to conclude with three observations and questions for further research that grow out of a certain weakness of Khosla's analysis where it comes to the global contextualization of the Indian experience.

The first has to do with the relevant reference points for analyzing and understanding India's founding moment and constitutional experience. It is striking how often and prominently Khosla refers to the USA as a central reference point. To some extent, this is not surprising given the prominent role of the USA as a leading democratic nation in the middle of the twentieth century and the experiences that in particular Ambedkar and Rau (but also Madhav Khosla himself)

\footnotetext{
4 Also surprising is that the issue of electoral systems and the decision for majority voting and the rejection of proportionate voting only appears in a footnote of Khosla's analysis. Given that the partly problematic effects of proportionate voting (in partly fragmentation) were well-known at the time and devices against them emerged (in particular thresholds), there could be gained more.
} 
had collected there. At the same time and looking at the actual Indian constitution as it emerges, the US influence in substance seems rather limited. In fact, for the structural aspects, the Indian constitutional legislature does not (as did the Latin American states) copy the US presidential system but rather adopt the British style of parliamentary democracy. The Indian Constitution is also guided by a certain a preference for the executive over the legislature-in contrast to the US model, in which the branches are balanced more evenly. The Indian constitution also includes socio-economic aims, very much in contrast to the US. To some extent, Khosla's analysis triggers but not really answers the question about the balance between path-dependency (leaning towards English formats) and innovation (allowing new elements from diverse origins to take root) in constitutional design. This leads to the wider question of further influences and reference points. The Latin American constitutions and their commentators come to mind, the Irish-but also (at least from my perspective) the German and continental European constitutional experiences. These might have been (at least to some extent) inaccessible for the Indian protagonists at the time because of language barriers. But one wonders what else could be unearthed in terms of exchanges and understanding, since there is so much that resonates between for example the Indian and the German constitutional experience. And at least today, there should be resources and paths enough to contextualize and compare the Indian constitutional experience of the past 70 odd years in a much broader frame.

My second observation concerns the characterization of India's model of constitutional democracy and the question of it being a distinct model that goes beyond liberalism. Looking at Khosla's characterization from afar, one might be excused to perceive it first as a somewhat typical example of a liberal constitutional democracy: rights spelled out in a written constitution, a centralized state, representative democracy. But throughout Khosla's analysis, particularities and differences in the conception of these elements occur. So one wonders whether these differences that do occur are simply separate, unconnected 'odd details' —or whether they form a somehow consistent alternative model of constitutional democracy that the Indian Constitution inaugurates. Some important elements are mentioned-such as the material dimension of a social (economic) democracy (conveyed through directive principles and the preamble) and the regard for certain group rights in the political process, in particular quota for backward classes. But one can also ponder further elements of an Indian theory of constitutional democracy that are missing here but would need to be included. One would in particular want to understand better the role of religion and the choice for secularism in the political system; the conception of judicial review and of the idea of separation of powers more generally; the constitutional role that the founders saw for political parties and elections in the system, and finally of speech and the organization of the public sphere.

And one final thought: Khosla is interested only in the historical moment of the founding, which is a perfectly fine limitation. But while reading his book, one cannot but think about the latter experience of this Constitution-and reach a certain melancholic observation: as much as the constructivist idea of constitutional democracy explains the constitutional model at the founding, it also serves as a foil for others to construct their constitutional model. In the dark days today, as the Indian 
Constitution is reconstructed in a Hindu nationalist way (and the state re-directed and representation undermined), little seems left of a shared constitutional morality but instrumental use gains the upper hand.

Funding Open Access funding enabled and organized by Projekt DEAL.

\section{Declarations}

Conflict of Interest The author declares no competing interests.

Open Access This article is licensed under a Creative Commons Attribution 4.0 International License, which permits use, sharing, adaptation, distribution and reproduction in any medium or format, as long as you give appropriate credit to the original author(s) and the source, provide a link to the Creative Commons licence, and indicate if changes were made. The images or other third party material in this article are included in the article's Creative Commons licence, unless indicated otherwise in a credit line to the material. If material is not included in the article's Creative Commons licence and your intended use is not permitted by statutory regulation or exceeds the permitted use, you will need to obtain permission directly from the copyright holder. To view a copy of this licence, visit http://creativecommons.org/licen ses/by/4.0/.

\section{References}

Bajpai J (2015) Debating difference. Oxford University Press, Oxford

Dann P (2020) The Global South and Comparative Constitutional Law. Oxford University Press, Oxford

Dann P Thiruvengadam A. (2021) Comparing constitutional democracy. In Dann P. Thiruvengadam A.

(eds.) Democratic constitutionalism in India and the European Union: comparing the law of democracy in continental polities, Edward Elgar Publishing, forthcoming.

Jayal NG (2013) Citizenship and its discontents: an Indian history. Harvard University Press, Harvard Kumar A (2015) Radical equality. Stanford University Press, Stanford Sujit C (2007) Migration of constitutional ideas. Cambridge University Press, Cambridge Zachariah B (2005) Developing India. Oxford University Press, Oxford

Publisher's Note Springer Nature remains neutral with regard to jurisdictional claims in published maps and institutional affiliations. 